OPEN ACCESS

Edited by:

Marius Nils Müller,

Federal University of Pernambuco,

Brazil

Reviewed by:

Frank Pavia,

California Institute of Technology,

United States

Tom Trull,

Commonwealth Scientific

and Industrial Research Organisation

(CSIRO), Australia

*Correspondence: Jenan J. Kharbush jenanjk@umich.edu

Specialty section:

This article was submitted to

Marine Biogeochemistry,

a section of the journal

Frontiers in Marine Science

Received: 09 March 2020

Accepted: 05 June 2020

Published: 26 June 2020

Citation:

Kharbush JJ, Close HG

Van Mooy BAS, Arnosti C,

Smittenberg RH, Le Moigne FAC,

Mollenhauer G, Scholz-Böttcher B,

Obreht I, Koch BP, Becker KW, Iversen MH and Mohr W (2020)

Particulate Organic Carbon

Deconstructed: Molecular

and Chemical Composition

of Particulate Organic Carbon

in the Ocean. Front. Mar. Sci. 7:518.

doi: 10.3389/fmars.2020.00518

\section{Particulate Organic Carbon Deconstructed: Molecular and Chemical Composition of Particulate Organic Carbon in the Ocean}

\author{
Jenan J. Kharbush ${ }^{1 *}$, Hilary G. Close ${ }^{2}$, Benjamin A. S. Van Mooy ${ }^{3}$, Carol Arnosti ${ }^{4}$, \\ Rienk H. Smittenberg ${ }^{5}$, Frédéric A. C. Le Moigne ${ }^{6}$, Gesine Mollenhauer, \\ Barbara Scholz-Böttcher ${ }^{9}$, Igor Obreht ${ }^{8}$, Boris P. Koch ${ }^{7}$, Kevin W. Becker ${ }^{10}$, \\ Morten H. Iversen ${ }^{7,8}$ and Wiebke Mohr ${ }^{11}$
}

${ }^{1}$ Department of Earth and Environmental Science, University of Michigan, Ann Arbor, MI, United States, ${ }^{2}$ Rosenstiel School of Marine and Atmospheric Science, University of Miami, Miami, FL, United States, ${ }^{3}$ Department of Marine Chemistry and Geochemistry, Woods Hole Oceanographic Institution, Woods Hole, MA, United States, ${ }^{4}$ Department of Marine Sciences, University of North Carolina at Chapel Hill, Chapel Hill, NC, United States, ${ }^{5}$ Department of Geological Sciences, Stockholm University, Stockholm, Sweden, ${ }^{6}$ Mediterranean Institute of Oceanography (UM 110, MIO), CNRS, IRD, Aix Marseille Université, Marseille, France, ${ }^{7}$ Alfred Wegener Institute for Polar and Marine Research, Bremerhaven, Germany,

${ }^{8}$ MARUM-Center for Marine Environmental Sciences, University of Bremen, Bremen, Germany, ${ }^{9}$ Institute for Chemistry and Biology of the Marine Environment (ICBM), Carl von Ossietzky University of Oldenburg, Oldenburg, Germany,

${ }^{10}$ GEOMAR Helmholtz Centre for Ocean Research Kiel, Kiel, Germany, " Department of Biogeochemistry, Max Planck Institute for Marine Microbiology, Bremen, Germany

The dynamics of the particulate organic carbon (POC) pool in the ocean are central to the marine carbon cycle. POC is the link between surface primary production, the deep ocean, and sediments. The rate at which POC is degraded in the dark ocean can impact atmospheric $\mathrm{CO}_{2}$ concentration. Therefore, a central focus of marine organic geochemistry studies is to improve our understanding of POC distribution, composition, and cycling. The last few decades have seen improvements in analytical techniques that have greatly expanded what we can measure, both in terms of organic compound structural diversity and isotopic composition, and complementary molecular omics studies. Here we provide a brief overview of the autochthonous, allochthonous, and anthropogenic components comprising POC in the ocean. In addition, we highlight key needs for future research that will enable us to more effectively connect diverse data sources and link the identity and structural diversity of POC to its sources and transformation processes. Keywords: marine particles, water column, phytoplankton, marine microbes, structural analysis, organic matter
characterization, biomarkers

\section{INTRODUCTION}

Particulate organic carbon (POC) is operationally defined as all combustible, non-carbonate carbon that can be collected on a filter. The oceanographic community has historically used a variety of filters and pore sizes, most commonly $0.7,0.8$, or $1.0 \mu \mathrm{m}$ glass or quartz fiber filters. The biomass of living zooplankton is intentionally excluded from POC through the use of a prefilter or specially designed sampling intakes that repel swimming organisms. Sub-micron particles, including most ocean prokaryotes, which are $0.2-0.8 \mu \mathrm{m}$ in diameter, are often not captured but should be considered part of POC rather than dissolved organic carbon (DOC, recently reviewed 
in Wagner et al., 2020), which is usually operationally defined as $<0.2 \mu \mathrm{m}$. Here, we consider POC to contain suspended and sinking particles $\geq 0.2 \mu \mathrm{m}$ in size, which therefore includes biomass from living microbial cells, detrital material including dead cells, fecal pellets, other aggregated material, and terrestrially-derived organic matter. Some studies further divide POC operationally based on its sinking rate (Riley et al., 2012) or size, with $\geq 51 \mu \mathrm{m}$ particles sometimes equated to the sinking fraction (e.g., Lam et al., 2011). Both DOC and POC play major roles in the carbon cycle, but POC is the major pathway by which OC produced by phytoplankton is exported -mainly by gravitational settling - from the surface to the deep ocean and eventually to sediments, and is thus a key component of the biological pump (Eppley and Peterson, 1979; Volk and Hoffert, 1985; Boyd and Trull, 2007; Cavan et al., 2015; Boyd et al., 2019; Le Moigne, 2019).

Accurately modeling the ocean carbon cycle requires both quantitative and qualitative understanding of POC production, composition, transformation, and cycling. Decades of measurements and modeling efforts have made significant progress toward this understanding, but persistent questions remain: How much POC is in the oceans? What determines POC spatial distribution and molecular composition? What is the residence time of POC? What regulates exchange between POC and DOC? What processes control the delivery of POC from surface waters to the mesopelagic? What controls degradation and preservation of POC delivered to marine sediments (Arnosti et al., 2019, this issue)?

Many marine organic geochemical investigations attempt to answer these questions from the bottom up, through characterization and quantification of the molecules that make up POC. Notably, because POC encompasses most living cells in the ocean, a considerable proportion of POC (particularly "fresh" POC collected in the upper ocean) is identifiable at the biomolecular level. This contrasts with DOC and sedimentary organic matter, which are predominantly non-cellular and molecularly uncharacterizable (Hedges et al., 2000; Kujawinski, 2011; Hansell, 2013), and implies that molecular-level understanding of POC can provide both qualitative and quantitative information. Major ocean surveys in the 1980s (VERTEX) and 1990s (JGOFS) demonstrated that the biochemical composition of POC was more dynamic and informative than expected from analysis of bulk POC data alone (Wakeham et al., 1984, 1997, 2000). Since then, improvements in analytical techniques have resulted in increasingly detailed studies of POC components in efforts to unmask what Hedges et al. (2000) called biogeochemical "trump cards" hidden by a lack of detailed structural knowledge. Regardless, structural understanding of POC has yet to be translated into parameterizations for carbon cycle models; global biogeochemical ocean models vary widely in their formulation of POC composition and reactivity (e.g., Bendtsen et al., 2015; Weber et al., 2016).

Importantly, there are various scientific motivations for studying POC that determine which organic compounds are characterized in specific studies. For example, biological oceanography or microbial ecology studies examining living components or biological responses are more likely to target labile compounds and small size classes of POC. Chemical oceanography or carbon cycle studies, on the other hand, often consider POC as a bulk, non-living material sinking through the water column, and are therefore more likely to target compounds that may indicate bulk POC sources and lability, and to sample sinking particles. Paleoceanography or "modern analog" approaches may be unconcerned about the bulk properties of POC and instead focus on specific recalcitrant compounds that can be preserved in sediments and serve as indicators of environmental conditions. Still other studies are focused on anthropogenic impacts, and therefore target anthropogenic compounds like plastics, often without contextualizing their quantity in relation to naturally occurring materials in POC. Though seemingly very different, these applications all fall within the framework of organic geochemistry of POC.

Overall, a molecular-level view of POC enables us to explore the biological, chemical, and metabolic processes that underlie carbon cycling in the ocean (Figure 1), in order to better understand OC reactivity, its relationship to food web composition and dynamics, how and why the composition of POC changes with depth in the water column, and the types and quantity of carbon exported to sediments. In this overview based on discussions from a recent workshop ${ }^{1}$, we briefly highlight the current understanding, recent developments, and knowledge gaps for the major components of POC. We discuss autochthonous sources of POC produced mostly by phytoplankton in surface waters as well as allochthonous material exported from terrestrial environments.

\section{AUTOCHTHONOUS COMPONENTS OF POC}

\section{Lipids}

All living cells and many viruses contain lipids, which we define here as molecules that are insoluble in water but extractable by non-polar solvents such as chloroform, dichloromethane, and hexane (McNaught and Wilkinson, 1997; Killops and Killops, 2005; Luo et al., 2019). Under this definition, lipids comprise hundreds of thousands of distinct molecules including photosynthetic pigments, hydrocarbons, and glycerol esters/ethers. Functions range from the foundation of cell membrane structure to energy storage, electron transport, signaling, reactive oxygen species scavenging, and light harvesting. Lipids comprise $\sim 20 \%$ of OC in living cells but are usually only a small percentage of sedimentary OC (Wakeham et al., 1997; Wang and Druffel, 2001), and may therefore contribute to the formation of recalcitrant molecularly uncharacterized organic matter (MUC, section "The Molecularly Uncharacterized Component (MUC) of POC"; Hwang and Druffel, 2003). Recent analytical advancements allow us to take advantage of lipid structural diversity to connect organismal ecology and physiology with POC cycling, through both targeted

\footnotetext{
1 "Future Directions in Marine Organic Biogeochemistry" held at the Hanse Institute for Advanced Study, Delmenhorst, Germany; April 27-30, 2019.
} 


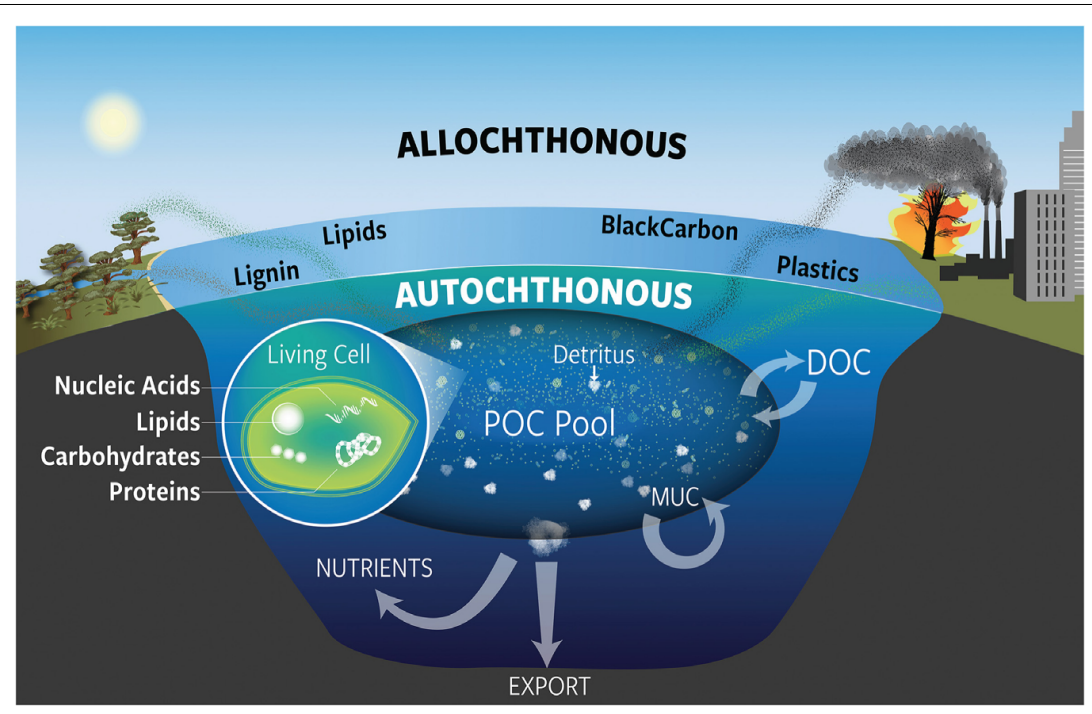

FIGURE 1 | Conceptual overview of marine particulate organic carbon (POC) in the ocean. POC includes components of living cells as well as dead material (detritus), and originates from both allochthonous and autochthonous sources. The POC pool can also exchange material with the dissolved OC (DOC) pool through aggregation and disaggregation of particles. This process and others may be involved in the formation of the molecularly uncharacterized component (MUC), which may incorporate both autochthonous and allochthonous OC.

studies of specific lipid biomarkers and untargeted surveys of the entire POC lipidome (Kharbush et al., 2016; Becker et al., 2018; Sollai et al., 2019).

Lipids and pigments are commonly employed as biomarkers because many of them are synthesized by specific organisms, allowing their sources to be traced within POC pools. Recalcitrant lipid biomarkers have been heavily pursued within POC as indicators that can be exported to sediments and therefore preserve a geologic snapshot of water column metabolisms. For example, pigments like chlorophylls, carotenoids, and their degradation products are used to track phytoplankton-derived POC through the water column (Repeta and Gagosian, 1984; Llewellyn and Mantoura, 1996). Sterol lipid biomarkers exist for a range of planktonic organisms (Wakeham and Beier, 1991; Volkman, 2016). Ladderane lipids are specific to anaerobic ammonia-oxidizing bacteria and thus identify the presence of this metabolism (Sinninghe Damsté et al., 2002). Fatty acids are the non-polar core components of glycerol-based membrane lipids in bacteria and eukaryotes and have long been characterized in POC, and isoprenoid biphytane lipids compose the nonpolar core of archaeal membranes. Core lipids are relatively recalcitrant, and some are structurally distinct enough to be used as biomarkers, especially when combined with compoundspecific isotope analysis (CSIA, Ingalls et al., 2006; Popendorf et al., 2011; Close et al., 2014). Preserved core lipids in sediments can also be proxies for past environmental conditions (Prahl and Wakeham, 1987; Schouten et al., 2002; Belt et al., 2007), but interpreting these proxies requires thoroughly understanding lipid production, transformation, and diagenesis processes (e.g., Hurley et al., 2016; Ding et al., 2019).

Studying the living components of POC often involves sampling microbial size classes $(>0.2 \mu \mathrm{m})$ and targeting more specific, labile structures. For instance, analyzing glycerolipids with their polar headgroups still intact (i.e., intact polar lipids, IPLs) using high-resolution mass spectrometry added a new dimension to the development of lipidomic "fingerprints" for specific microbes and their metabolic status. The microbial lipidome can reflect adjustments made in response to changes in external variables like temperature, $\mathrm{pH}$, or nutrient concentrations. Under low phosphorus (P) conditions, sulfur or nitrogen-containing lipids can be used in place of phospholipids (Van Mooy et al., 2009), making these non-P-containing IPLs useful for studying carbon cycling under P-limitation (Kharbush et al., 2016; Schubotz et al., 2018). The molecular distribution of glycerol-dialkyl(dibiphytane)-glycerol tetraethers (GDGTs) produced by pelagic archaea also appear to reflect environmental factors, including temperature (Elling et al., 2015; Zhou et al., 2020). It is often assumed that IPLs degrade rapidly upon cell death and that they can be used to study in situ activity of the living microbial component separately from non-living detrital POC. This assumption, however, rests on limited experimental evidence (White et al., 1979; Harvey et al., 1986) and should be revisited (e.g., Logemann et al., 2011), as defining the fraction of living and detrital POC is of urgent importance for understanding POC export to the deep-sea and sediment.

Lipid biomarkers are especially useful in investigating oceanographic processes that impact POC and the biological pump; for example, as indicators for the degradation state of POC, or which microbial groups are contributing to POC production, degradation, or export. The development and increased access to high-resolution mass spectrometry has resulted in the identification of many more biomarker structures, providing increased statistical power in lipidomics studies (e.g., Becker et al., 2018). An additional frontier is devising approaches to rigorously link lipidomics and other types of data. For example, lipid and genetic biomarkers were recently combined 
with satellite data to show that viral infection of coccolithophore blooms enhances vertical flux and export of POC (Laber et al., 2018). Becker et al. (2018) discovered that daily oscillations in triacylglycerol concentrations accounted for about $6 \%$ of primary production, and used metatranscriptomics to implicate specific lineages of phytoplankton as sources of these lipids. These examples show that although lipids make up a minor component of total biomass and POC, their source-specificity can be capitalized upon to elucidate novel POC cycling and export pathways, particularly when lipid data are combined with other omics data.

\section{Amino Acids and Proteins}

Hydrolyzable amino acids (AAs) are the most abundant identifiable component of marine POC (Wakeham et al., 1997) and have been studied for decades. AA sources in POC include living autotrophic and heterotrophic cells, as well as detritus, and the relative contribution of each of these varies with depth (Kawasaki et al., 2011). While the same protein-forming L-amino acids are found in all living things, heterotrophic organisms both remineralize AAs and alter the relative concentration of individual AAs during export to depth (Van Mooy et al., 2002; Engel et al., 2017). These compositional changes have been developed into "degradation indices" (e.g., Dauwe et al., 1999) that are used are indicators of OC freshness. Similarly, the enantiomeric (D/L) AA composition of POC is used to estimate the heterotrophic bacterial contribution to POC, as certain D-AA derive exclusively from bacterial cell walls. Using this method, the total contribution from living and detrital bacterial cells in openocean surface waters was estimated to be between 15 and $25 \%$ of suspended POC (Kaiser and Benner, 2008; Kawasaki et al., 2011; Tremblay et al., 2015).

The stable isotope ratios of $\mathrm{C}$ and $\mathrm{N}$ in different AAs form patterns related to the biosynthetic source and/or history of passage through heterotrophic metabolisms. Compound specific isotope analysis of AAs (CSIA-AA) thus is beginning to provide unique insights into the cycling of POC and sedimentary AAs (Batista et al., 2014; Sabadel et al., 2019). Nitrogen CSIA-AA is frequently used to estimate trophic position (e.g., Chikaraishi et al., 2009), and alongside other AA degradation indices can trace heterotrophic bacterial activity (Calleja et al., 2013). Carbon CSIA-AA has been used to differentiate various phytoplankton, heterotrophic bacterial, and allochthonous terrigenous sources within POC and sediments (Hannides et al., 2013; Larsen et al., 2015; McMahon et al., 2015). However, our understanding of the mechanisms that influence isotope fractionation patterns of AA is still incomplete. Of particular interest is elucidating how various microbial processes affect amino acid isotope values. For instance, heterotrophic bacteria acquire AAs in several ways, including de novo synthesis, extracellular uptake, or "resynthesizing" them from other AAs (Ohkouchi et al., 2017). Each may have different isotope fractionation patterns, and unless these are robustly known it could complicate interpretation of CSIA-AA patterns.

POC also contains identifiable proteins, as components of living cells or preserved in detrital material (Dong et al., 2010; Moore et al., 2012). Marine metaproteomics is an emerging technique that links genetic potential with metabolic function, including in particle-associated microbial communities (Bridoux et al., 2015), although challenges remain for data analysis and interpretation (Saito et al., 2019). Although not yet widely applied in marine systems, protein stable isotope probing approaches could further pinpoint in situ metabolic activity, yielding simultaneous determination of both phylogeny and metabolic function of specific organisms. This could be useful in determining the role of heterotrophic microbes in degradation and cycling of phytoplankton-derived POC, or in the formation of MUC.

\section{Carbohydrates}

Carbohydrates are important structural components and energy storage compounds in photosynthetic organisms, constituting $\sim 21-50 \%$ of phytoplankton biomass (Biersmith and Benner, 1998), $>50 \%$ of macroalgal biomass (Mabeau and Kloareg, 1987), and $8-10 \%$ of suspended POC and $3-18 \%$ of sinking POC (Panagiotopoulos and Sempéré, 2005). A significant fraction of carbohydrates biosynthesized by primary producers is thus transformed and remineralized, but some is preserved as detrital components of OC (Wakeham et al., 1997). What production and transformation processes govern carbohydrate dynamics? What factors distinguish carbohydrates that fuel the food web from carbohydrates that are part of the detrital POM pool? These simple questions have complex answers (Arnosti et al., In press), starting with consideration of carbohydrate structures.

Carbohydrates are structurally highly diverse: individual sugars are monosaccharides, mostly either hexoses or pentoses. Monosaccharides are polymerized into disaccharides (two units), oligosaccharides ( $\sim 10$ units), and polysaccharides ( $>10$ unites). Monosaccharides are linked via hydroxyl groups in a vast diversity of linkage conformations; in theory, three different hexoses could lead to 128 different disaccharides (Laine, 1994). Oligo- and polysaccharides are often branched or contain sulfate, methyl, or amino groups, adding further structural complexity and frequently requiring "matching" enzymes to remove the sulfate, methyl, or amino groups prior to degradation of the polysaccharide backbone (e.g., Reisky et al., 2019). The structural diversity of carbohydrates thus could be used to link detrital components back to their sources, but only recently has progress been made in analytical techniques to begin to characterize these structures with sufficient resolution.

Carbohydrates are frequently measured using colorimetric techniques, providing bulk quantitative measurements but little structural information. Analysis of carbohydrate monomers that break carbohydrate polymers into monomers is more informative, but, like a collection of bricks without the blueprint of the building, leaves us wondering about the original structure. In addition, polysaccharide hydrolysis can destroy some component monosaccharides and fail to hydrolyze others. A paradox remains: the reactivity of carbohydrates ranges from very rapid, as for glucose or energy storage polysaccharides like laminarin, to very slow, as evidenced by the presence of carbohydrates in turbidites over 140,000 years old (Cowie et al., 1995). Carbohydrates constitute a substantial fraction of POC, but without the techniques to determine 
specific structures, we have few means to read the messages they could convey. Fortunately, emerging analytical approaches may provide additional structural information: for example, improved chromatographic separations allow compound-specific isotope analysis of individual carbohydrates (Nouara et al., 2019), and specific polysaccharide-hydrolyzing enzymes enable quantification of laminarin in POC (Becker et al., 2017, 2020). Use of carbohydrate microarrays provides new insights into the presence and structure of specific complex carbohydrates in marine samples (Salmeán et al., 2018; Koch et al., 2019). Such techniques can enable us to decipher the specific structures - and therefore the origins, transformations, and relative reactivity - of more of the substantial carbohydrate-containing fraction of POC.

\section{Nucleic Acids}

Nucleic acids are the ultimate biomarkers for the living or recently living components of POC, as they can reveal the taxonomic identities and metabolic potential of both photosynthetic producers of POC and heterotrophic organisms that transform POC. Free-living microbial communities are captured as small particles and particle-attached communities are associated with larger suspended and sinking particles (DeLong et al., 1993); investigating these communities can provide critical insight into POC production, export, and attenuation processes. RNA and DNA can distinguish between living, active cells and dead or dormant material, respectively, and enable identification of organisms that are difficult to culture or observe microscopically. Studies can focus on specific genes or use untargeted omics approaches. Commonly applied phylogenetic markers are the $16 \mathrm{~S}$ (prokaryotic) and $18 \mathrm{~S}$ (eukaryotic) rRNA genes, used to examine the phylogenetic composition of POCassociated communities and how they change with depth, environmental conditions, and over time (DeLong et al., 2006; Duret et al., 2019; Thiele et al., 2019; Preston et al., 2020).

$16 \mathrm{~S} / 18 \mathrm{~S}$ rRNA and other single functional gene approaches reveal "who" is there, but not much insight into "what" they are doing or "how." Metagenomics/transcriptomics can provide focused insight into the metabolic capabilities of the whole community, and also of distinct community members using metagenomics-assembled genomes (Krüger et al., 2019). Major progress has been made through concerted study of spring phytoplankton blooms (Teeling et al., 2012, 2016) as well as global ocean surveys of microbial communities (e.g., Tara Oceans, Bork et al., 2015), and patterns pertaining to POC cycling are beginning to emerge (Guidi et al., 2016). Future advances depend on continuing these international sampling efforts to incorporate biological and chemical measurements across multiple temporal and spatial scales (e.g., Biogeoscapes) ${ }^{2}$.

Though challenging, integrating molecular omics approaches with organic geochemistry is important to link the chemical composition of POC with biological processes, which are likely very important in regulating exchange between $\mathrm{POC}$ and DOC pools, and in determining the amount of POC ultimately delivered to marine sediments vs. remineralized vs. sequestered as refractory DOC (the "microbial carbon pump," Jiao et al., 2010;

${ }^{2}$ www.biogeoscapes.org
Legendre et al., 2015). However, so far we lack sufficient data on both biological as well as chemical composition of different types of particles across varying temporal and spatial scales. To address this knowledge gap some recent studies have begun to examine the relationship of particle size/type with microbial community composition and metabolism using next-generation omics techniques. For example, metagenomics and transcriptomics were recently used to infer the metabolic activities of prokaryotic and eukaryotic communities on sinking particles in the deep sea, which indicated considerable midwater trophic processing of sinking POC by deep water protists and animals (Boeuf et al., 2019). Additionally, distinct prokaryotic assemblages were associated with suspended vs. sinking particles (Duret et al., 2019), and between different particle size classes (Mestre et al., 2017, 2018). This may suggest that particle compositions foster different metabolisms or modes of colonization, but remains hypothetical without concurrent chemical data.

\section{ALLOCHTHONOUS COMPONENTS OF POC}

\section{Lignin and Terrestrial Plant Biomarkers}

Vascular-plant derived molecules are used as quantitative tracers of terrestrially derived OC. Long-chain $n$-alkanes and fatty acids are synthesized by vascular plants as a component of leaf waxes, which are most abundant in coastal areas, but can be transported into the ocean with atmospheric dust or through riverine inputs. Lignin, a group of phenolic polymers, is probably the most well-studied terrestrial biomarker, as it is only produced by vascular plants and comprises one third of their biomass on average. Lignin is relatively stable in marine environments and has been used to quantify the amount of POC and DOC derived from plants and to determine plant tissue type and degradation state (Gordon and Goñi, 2004; Hernes and Benner, 2006). In the open ocean lignin is usually a minor component of POC, possibly because it is photo-oxidized, microbially degraded, or transformed into refractory molecules such as chromophoric DOC (CDOM, e.g., McDonald et al., 2019). However, higher concentrations of lignin and lignin phenols have been observed in POM in deep water masses, suggesting that terrestrial OM may be a quantitatively important component of POM in the bathypelagic (Hernes and Benner, 2002, 2006). Lignin-derived molecules are also important for tracing and quantifying terrestrial carbon import and export in coastal ecosystems, especially "blue carbon" ecosystems like salt marshes, mangrove forests and seagrass meadows. So far it has been difficult to quantify how much different sources of terrestrial carbon contribute to marine POC and DOC pools, and how much is sequestered in estuaries and coastal sediments (reviewed in Cragg et al., 2020). Recent studies are making progress in separating distinct terrestrial contributions to POC by combining ${ }^{13} \mathrm{C}$ and radiocarbon CSIA of lignin and other biomarkers (e.g., Tao et al., 2015), and in identifying biological degradation pathways (Woo and Hazen, 2018). 


\section{Black Carbon}

Black carbon (BC) is produced from incomplete combustion during wildfires and burning fossil fuels, and is found in both dissolved (DBC) and particulate (PBC) pools in the ocean (see Wagner et al., 2018 for detailed review of DBC). Marine PBC is primarily attributed to the absorption of DBC to POC. It spans a range of forms and reactivities, from slightly charred plant material to highly refractory, graphitized soot (the "combustion continuum," Hedges et al., 2000). PBC is enriched in carbon relative to its biological sources and is difficult to characterize structurally because it is dominated by polyaromatic structures, is insoluble, and resists chemical degradations. This is likely why $\mathrm{PBC}$ is refractory and decomposes slowly; radiocarbon data show that marine $\mathrm{PBC}$ can be tens of thousands of years old (Coppola et al., 2018). PBC represents a significant part of global carbon budgets, and in some locations comprises up to $20 \%$ of total POC and up to $50 \%$ of the MUC pool in POC (e.g., Gulf of Maine, Flores-Cervantes et al., 2009).

Because of its recalcitrance, PBC may contribute significantly to OC sequestration in marine sediments, however, this quantity is difficult to estimate because $\mathrm{PBC}$ reactivity and loss processes are poorly known. Recent work suggests that DBC in the open ocean may not originate from riverine transport, but from another, unidentified source, as its $\delta^{13} \mathrm{C}$ values differ from riverine DBC (Wagner et al., 2019), and there are low concentrations of other terrigenous compounds in the open ocean (Hedges et al., 1997). Further isotopic studies could constrain potential sources (e.g., aerosols, autochthonous OC, hydrothermal vents) and reveal photo-oxidative or other degradative alteration processes.

\section{Microplastics}

Plastics are a recent but now widespread anthropogenic addition to marine POC (Law, 2017). Plastic particles between $1 \mu \mathrm{m}$ and $5 \mathrm{~mm}$ in size are termed microplastics (MPs). MPs $>100 \mu \mathrm{m}$ are the most commonly studied; however, the number of plastic particles increases exponentially with decreasing particle size. Because most POC is also $<100 \mu \mathrm{m}$ in size, the contribution of MP to total POC is poorly known.

Physical forms of MPs include pellets, fragments, fibers, and foils, representing either their originally manufactured size range or alteration during physical and photochemical processes that fragment larger into smaller pieces. Depending on polymer density, MPs may float, sink, or be suspended at intermediate depths. Over time the physical and chemical properties of MPs can also be altered by weathering, embrittlement, fragmentation, and microbial colonization (Bryant et al., 2016).

MPs have been found across all oceans, from the surface to deep sea trenches (Peng et al., 2020). In sediments MPs are accumulating at rates that may leave a stratigraphic signal of the Anthropocene in the geological record (Zalasiewicz et al., 2016). However, the abundance of MPs throughout the marine environment is heterogeneous and inadequately quantified across varying spatial scales, and the processes that distribute MPs among surface, water column, and sediments are poorly understood. Many plastics also contain chemical additives, and their effects on marine species are not well studied.
These knowledge gaps will need to be addressed before we can assess the effects of MPs on marine ecosystems, but new research suggests that MPs could affect the biological pump. For example, laboratory experiments showed that MPs could be ingested by zooplankton, changing the density and sinking rates of their fecal pellets (Cole et al., 2016). In addition, incorporation of MPs can alter particle structure and density, and affect sinking and remineralization rates or influence POC aggregation/disaggregation (Chen et al., 2018; Porter et al., 2018).

\section{THE MOLECULARLY UNCHARACTERIZED COMPONENT (MUC) OF POC}

A large fraction of POC is considered "uncharacterizable" because it cannot be separated and identified using traditional chromatography-based molecular analyses. This appropriately abbreviated "MUC" increases in concentration relative to characterizable POC components with increasing depth in the water column, even as the overall flux of POC decreases (Wakeham et al., 1997, 2000; Hedges et al., 2000). This observation suggests that MUC is either produced from transformation of characterizable surface-derived material during export (possibly lipids, Hwang and Druffel, 2003) or from incorporation of DOC deeper in the water column, or, alternatively, that our analytical methods do not adequately identify biomolecules whose presence is obscured in some manner (Hedges et al., 2001). Despite the analytical advancements of the last two decades, the formation and sources of MUC are still poorly understood; hypothesized mechanisms include degradative formation of geo- or biomacromolecules, incorporation of detrital material and/or black carbon, and interactions with inorganic mineral material. Other analytical methods applied to characterize bulk chemical features of MUC include advanced solid-state NMR and infrared spectroscopy techniques (e.g., Liu et al., 2009; Tremblay et al., 2011). In addition, bulk isotope ratios of POC are one of the few measurements that capture the entire POC pool, including MUC. Some studies have found spatial variations in bulk $\delta^{13} \mathrm{C}$ and $\Delta^{14} \mathrm{C}$ values of POC that suggest a substantial contribution to POC from ${ }^{14} \mathrm{C}$-depleted material not immediately derived from surface primary production, possibly from resuspended sediment, black carbon, or incorporation of "old" water column DOC (Roland et al., 2008; Hwang et al., 2010).

Identifying MUC sources and cycling is an area that merits further attention, but may be better addressed in the future through application of high-resolution or ultra-high-resolution mass spectrometry, as well as high-resolution solid-state NMR (Mao et al., 2011), which have the potential to expand the analytical window to simultaneously examine the molecular diversity of important compound classes (e.g., lipids), and also to identify novel structures or functional groups. Within DOC, new analytical tools and workflows are enabling structural information to be assigned for a growing number of molecular features (e.g., Petras et al., 2017), and metabolomics approaches also are beginning to be applied to POC (Johnson et al., 2020). 


\section{CONCLUDING REMARKS}

The development of new and improved analytical techniques now enables analysis of marine POC in greater molecular detail than ever before, with the potential to greatly expand our current catalog of organic biomarkers and other organic proxies and gain insight into the big questions about POC. However, studies of POC cycling in the ocean are fundamentally challenged by a long-standing limitation of established organic geochemical approaches: the most information-rich compounds or proxies tend to compose only tiny fractions of the bulk POC pool. In other words, using biomarkers to infer sources or cycling of more significant portions of POC necessarily involves making many assumptions about the consistencies of the relative initial ratios of biomarker to POC, and their relative reactivity. These assumptions become increasingly tenuous as POC is cycled and distanced from its source. Overcoming this tension between POC chemotaxonomy and biogeochemistry will mark a new era in the use of biomarkers to study POC.

The VERTEX (Martin et al., 1987) and JGOFS (Bowles and Livingston, 1997) ocean surveys were important first steps in understanding the nature and variability of POC composition but predated oceanographic omics data. On the other hand, the Tara Oceans expedition (Bork et al., 2015) successfully assembled a global metagenome of upper ocean biology but with the exception of pigments did not analyze molecular composition. In order to mechanistically tie together organic compositional information with the fate of the bulk POC pool we need more studies that make simultaneous omics, geochemical, and molecular measurements. Still in the planning stage, Biogeoscapes ${ }^{2}$ is one new global effort that proposes to do this across multiple temporal and spatial scales, with the ultimate goal of understanding how metabolic feedbacks and interactions underpin biogeochemistry and structure ocean ecosystems. A multi-dimensional global dataset of POC, analyzed using improved analytical methods and integrated with omics, physiological, and nutrient data, would be invaluable for addressing many of the still-unanswered questions about POC,

\section{REFERENCES}

Arnosti, C., Hinrichs, K. U., Coffinet, S., Wilkes, H., and Pantoja, S. (2019). The enduring questions: what's for dinner? Where's my knife? and Can I use my fingers? (Unanswered) questions related to organic matter and microbes in marine sediments. Front. Mar. Sci. 6:629. doi: 10.3389/fmars.2019.00629

Arnosti, C., Wietz, M., Brinkhoff, T., Hehemann, J.-H., Probandt, D., Zeugner, L., et al. (in press). The biogeochemistry of marine polysaccharides: sources, inventories, and bacterial drivers of the carbohydrate cycle. Ann. Rev. Mar. Sci. 13.

Batista, F. C., Ravelo, A. C., Crusius, J., Casso, M. A., and McCarthy, M. D. (2014). Compound specific amino acid $\delta 15 \mathrm{~N}$ in marine sediments: a new approach for studies of the marine nitrogen cycle. Geochim. Cosmochim. Acta 142, 553-569. doi: 10.1016/j.gca.2014.08.002

Becker, K. W., Collins, J. R., Durham, B. P., Groussman, R. D., White, A. E., Fredricks, H. F., et al. (2018). Daily changes in phytoplankton lipidomes reveal mechanisms of energy storage in the open ocean. Nat. Commun. 9:5179. doi: 10.1038/s41467-018-07346-z including how to integrate POC composition into new modeling platforms or even machine learning approaches.

In summary, several areas are promising frontiers for the study of POC: (1) Leveraging the power of structural diversity to identify sources and metabolic processes, (2) Effectively integrating omics and geochemical techniques, (3) Improving methods to characterize unidentified components of POC, (4) coupling isotopic $\left(\delta^{13} \mathrm{C}\right.$ and $\left.\Delta^{14} \mathrm{C}\right)$ and molecular investigations of POC and DOC. While future work aimed at these issues will undoubtedly require field surveys, we also emphasize that controlled laboratory and mesocosm experiments are essential to construct mechanistic interpretations of environmental observations and should not be neglected.

\section{AUTHOR CONTRIBUTIONS}

$\mathrm{JK}, \mathrm{BV}, \mathrm{HC}, \mathrm{CA}$, and RS wrote the manuscript based on the discussions and notes taken at the workshop, with input from all co-authors. All authors contributed to the article and approved the submitted version.

\section{FUNDING}

We thank the Hanse Institute for Advanced Studies (HWK) and the Deutsche Forschungsgemeinschaft (DFG, German Research Foundation) project number 422798570, as well as the Geochemical Society, for funding which made the workshop possible. CA was additionally supported by OCE-1736772. BV was additionally supported by NSF OCE- 1756254 .

\section{ACKNOWLEDGMENTS}

We would like to thank HWK staff for coordinating and organizing the logistics of the workshop, including travel, accommodations, and food services, which greatly enhanced the meeting experience and the outcomes.

Becker, S., Scheffel, A., Polz, M. F., and Hehemann, J. H. (2017). Accurate quantification of laminarin in marine organic matter with enzymes from marine microbes. Appl. Environ. Microbiol. 83, 1-14. doi: 10.1128/AEM.03389-3316

Becker, S., Tebben, J., Coffinet, S., Wiltshire, K., Iversen, M. H., Harder, T., et al. (2020). Laminarin is a major molecule in the marine carbon cycle. Proc. Natl. Acad. Sci. U.S.A. 117, 6599-6607. doi: 10.1073/pnas.1917001117

Belt, S. T., Massé, G., Rowland, S. J., Poulin, M., Michel, C., and LeBlanc, B. (2007). A novel chemical fossil of palaeo sea ice: IP25. Org. Geochem. 38, 16-27. doi: 10.1016/j.orggeochem.2006.09.013

Bendtsen, J., Hilligsøe, K. M., Hansen, J. L. S., and Richardson, K. (2015). Analysis of remineralisation, lability, temperature sensitivity and structural composition of organic matter from the upper ocean. Prog. Oceanogr. 130, 125-145. doi: 10.1016/j.pocean.2014.10.009

Biersmith, A., and Benner, R. (1998). Carbohydrates in phytoplankton and freshly produced dissolved organic matter. Mar. Chem. 63, 131-144. doi: 10.1016/ S0304-4203(98)00057-57

Boeuf, D., Edwards, B. R., Eppley, J. M., Hu, S. K., Poff, K. E., Romano, A. E., et al. (2019). Biological composition and microbial dynamics of sinking particulate 
organic matter at abyssal depths in the oligotrophic open ocean. Proc. Natl. Acad. Sci. U.S.A. 116, 11824-11832. doi: 10.1073/pnas.1903080116

Bork, P., Bowler, C., De Vargas, C., Gorsky, G., Karsenti, E., and Wincker, P. (2015). Tara Oceans studies plankton at planetary scale. Science 348:873. doi: $10.1126 /$ science.aac5605

Bowles, M. C., and Livingston, H. D. (1997). U.S. Joint Global Ocean Flux Study. Available online at: http://usjgofs.whoi.edu/overview.html (accessed May 25 2020).

Boyd, P. W., Claustre, H., Levy, M., Siegel, D. A., and Weber, T. (2019). Multifaceted particle pumps drive carbon sequestration in the ocean. Nature 568, 327-335. doi: 10.1038/s41586-019-1098-1092

Boyd, P. W., and Trull, T. W. (2007). Progress in Oceanography Understanding the export of biogenic particles in oceanic waters: is there consensus? Cell 72, 276-312. doi: 10.1016/j.pocean.2006.10.007

Bridoux, M. C., Neibauer, J., Ingalls, A. E., Nunn, B. L., and Keil, R. G. (2015). Suspended marine particulate proteins in coastal and oligotrophic waters. J. Mar. Syst. 143, 39-48. doi: 10.1016/j.jmarsys.2014.10.014

Bryant, J. A., Clemente, T. M., Viviani, D. A., Fong, A. A., Thomas, K. A., Kemp, P., et al. (2016). Diversity and activity of communities inhabiting plastic debris in the North Pacific Gyre. mSystems 1, 1-19. doi: 10.1128/msystems.00024- 16

Calleja, M. L., Batista, F., Peacock, M., Kudela, R., and McCarthy, M. D. (2013). Changes in compound specific $\delta 15 \mathrm{~N}$ amino acid signatures and $\mathrm{D} / \mathrm{L}$ ratios in marine dissolved organic matter induced by heterotrophic bacterial reworking. Mar. Chem. 149, 32-44. doi: 10.1016/j.marchem.2012.12.001

Cavan, E. L., Le Moigne, F. A. C., Poulton, A. J., Tarling, G. A., Ward, P., Daniels, C. J., et al. (2015). Attenuation of particulate organic carbon flux in the Scotia Sea, Southern Ocean, is controlled by zooplankton fecal pellets. Geophys. Res. Lett. 42, 821-830. doi: 10.1002/2014GL062744

Chen, C. S., Le, C., Chiu, M. H., and Chin, W. C. (2018). The impact of nanoplastics on marine dissolved organic matter assembly. Sci. Total Environ. 634, 316-320. doi: 10.1016/j.scitotenv.2018.03.269

Chikaraishi, Y., Ogawa, N. O., Kashiyama, Y., Takano, Y., Suga, H., Tomitani, A., et al. (2009). Determination of aquatic food-web structure based on compoundspecific nitrogen isotopic composition of amino acids. Limnol. Oceanogr. Methods 7, 740-750. doi: 10.4319/lom.2009.7.740

Close, H. G., Wakeham, S. G., and Pearson, A. (2014). Lipid and 13C signatures of submicron and suspended particulate organic matter in the Eastern Tropical North Pacific: implications for the contribution of Bacteria. Deep. Res. Part I Oceanogr. Res. Pap. 85, 15-34. doi: 10.1016/j.dsr.2013.11.005

Cole, M., Lindeque, P. K., Fileman, E., Clark, J., Lewis, C., Halsband, C., et al. (2016). Microplastics alter the properties and sinking rates of zooplankton faecal pellets. Environ. Sci. Technol. 50, 3239-3246. doi: 10.1021/acs.est. 5b05905

Coppola, A. I., Wiedemeier, D. B., Galy, V., Haghipour, N., Hanke, U. M., Nascimento, G. S., et al. (2018). Global-scale evidence for the refractory nature of riverine black carbon. Nat. Geosci. 11, 584-588. doi: 10.1038/s41561-0180159- 158

Cowie, G. L., Hedges, J. I., Prahl, F. G., and de Lance, G. J. (1995). Elemental and major biochemical changes across an oxidation front in a relict turbidite: an oxygen effect. Geochim. Cosmochim. Acta 59, 33-46. doi: 10.1016/00167037(94)00329-K

Cragg, S. M., Friess, D. A., Gillis, L. G., Trevathan-Tackett, S. M., Terrett, O. M., Watts, J. E. M., et al. (2020). Vascular plants are globally significant contributors to marine carbon fluxes and sinks. Ann. Rev. Mar. Sci. 12, 469-497. doi: 10.1146/ annurev-marine-010318-095333

Dauwe, B., Middelburg, J. J., Herman, P. M. J., and Heip, C. H. R. (1999). Linking diagenetic alteration of amino acids and bulk organic matter reactivity. Limnol. Oceanogr. 44, 1809-1914.

DeLong, E. F., Franks, D., and Alldredge, A. (1993). Phylogenetic diversity of aggregate-attached vs. free-living marine bacterial assemblages. Limnol. Oceanogr. 38, 924-934. doi: 10.2307/2838082

DeLong, E. F., Preston, C. M., Mincer, T., Rich, V., Hallam, S. J., Frigaard, N.-U., et al. (2006). Community genomics among stratified microbial assemblages in the ocean's interior. Science 311, 496-503. doi: 10.1126/science.1120250

Ding, Y., Bi, R., Sachs, J., Chen, X., Zhang, H., Li, L., et al. (2019). Lipid biomarker production by marine phytoplankton under different nutrient and temperature regimes. Org. Geochem. 131, 34-49. doi: 10.1016/j.orggeochem.2019.01.008

Dong, H. P., Wang, D. Z., Dai, M., and Hong, H. S. (2010). Characterization of particulate organic matters in the water column of the South China Sea using a shotgun proteomic approach. Limnol. Oceanogr. 55, 1565-1578. doi: 10.4319/lo.2010.55.4.1565

Duret, M. T., Lampitt, R. S., and Lam, P. (2019). Prokaryotic niche partitioning between suspended and sinking marine particles. Environ. Microbiol. Rep. 11, 386-400. doi: 10.1111/1758-2229.12692

Elling, F. J., Könneke, M., Mußmann, M., Greve, A., and Hinrichs, K. U. (2015). Influence of temperature, $\mathrm{pH}$, and salinity on membrane lipid composition and TEX86 of marine planktonic thaumarchaeal isolates. Geochim. Cosmochim. Acta 171, 238-255. doi: 10.1016/j.gca.2015.09.004

Engel, A., Wagner, H., Le Moigne, F. A. C., and Wilson, S. T. (2017). Particle export fluxes to the oxygen minimum zone of the eastern tropical North Atlantic. Biogeosciences 14, 1825-1838. doi: 10.5194/bg-14-1825-2017

Eppley, R. W., and Peterson, B. J. (1979). Particulate organic matter flux and planktonic new production in the deep ocean. Nature 282, 677-680. doi: $10.1038 / 282677 \mathrm{a} 0$

Flores-Cervantes, D. X., Plata, D. L., MacFarlane, J. K., Reddy, C. M., and Gschwend, P. M. (2009). Black carbon in marine particulate organic carbon: inputs and cycling of highly recalcitrant organic carbon in the Gulf of Maine. Mar. Chem. 113, 172-181. doi: 10.1016/j.marchem.2009.01.012

Gordon, E. S., and Goñi, M. A. (2004). Controls on the distribution and accumulation of terrigenous organic matter in sediments from the Mississippi and Atchafalaya river margin. Mar. Chem. 92, 331-352. doi: 10.1016/j. marchem.2004.06.035

Guidi, L., Chaffron, S., Bittner, L., Eveillard, D., Larhlimi, A., Roux, S., et al. (2016). Plankton networks driving carbon export in the oligotrophic ocean. Nature 532, 465-470. doi: 10.1038/nature16942

Hannides, C. C. S., Popp, B. N., Anela Choy, C., and Drazen, J. C. (2013). Midwater zooplankton and suspended particle dynamics in the North Pacific subtropical gyre: a stable isotope perspective. Limnol. Oceanogr. 58, 1931-1936. doi: 10. 4319/lo.2013.58.6.1931

Hansell, D. A. (2013). Recalcitrant dissolved organic carbon fractions. Ann. Rev. Mar. Sci. 5, 421-445. doi: 10.1146/annurev-marine-120710-100757

Harvey, H. R., Fallon, R. D., and Patton, J. S. (1986). The effect of organic matter and oxygen on the degradation of bacterial membrane lipids in marine sediments. Geochim. Cosmochim. Acta 50, 795-804. doi: 10.1016/0016-7037(86) 90355-90358

Hedges, J. I., Baldock, J. A., Gélinas, Y., Lee, C., Peterson, M., and Wakeham, S. G. (2001). Evidence for non-selective preservation of organic matter in sinking marine particles. Nature 409, 801-804. doi: 10.1038/35057247

Hedges, J. I., Eglinton, G., Hatcher, P. G., Kirchman, D. L., Arnosti, C., Derenne, S., et al. (2000). The molecularly-uncharacterized component of nonliving organic matter in natural environments. Org. Geochem. 31, 945-958. doi: 10.1016/ S0146-6380(00)00096-96

Hedges, J. I., Keil, R. G., and Benner, R. (1997). What happens to terrestrial organic matter in the ocean? Org. Geochem. 27, 195-212. doi: 10.1016/S0146-6380(97) 00066-61

Hernes, P. J., and Benner, R. (2002). Transport and diagenesis of dissolved and particulate terrigenous organic matter in the North Pacific Ocean. Deep. Res. Part I Oceanogr. Res. Pap. 49, 2119-2132. doi: 10.1016/S0967-0637(02)00128120

Hernes, P. J., and Benner, R. (2006). Terrigenous organic matter sources and reactivity in the North Atlantic Ocean and a comparison to the Arctic and Pacific oceans. Mar. Chem. 100, 66-79. doi: 10.1016/j.marchem.2005.11.003

Hurley, S. J., Elling, F. J., Könneke, M., Buchwald, C., Wankel, S. D., Santoro, A. E., et al. (2016). Influence of ammonia oxidation rate on thaumarchaeal lipid composition and the TEX86 temperature proxy. Proc. Natl. Acad. Sci. U.S.A. 113, 7762-7767. doi: 10.1073/pnas.15185 34113

Hwang, J., and Druffel, E. R. M. (2003). Lipid-like material as the source of the uncharacterized organic carbon in the ocean? Science 299, 881-884. doi: 10. 1126/science. 1078508

Hwang, J., Druffel, E. R. M., and Eglinton, T. I. (2010). Widespread influence of resuspended sediments on oceanic particulate organic carbon: insights from radiocarbon and aluminum contents in sinking particles. Global Biogeochem. Cycles 24:GB4016. doi: 10.1029/2010GB003802

Ingalls, A. E., Shah, S. R., Hansman, R. L., Aluwihare, L. I., Santos, G. M., Druffel, E. R. M., et al. (2006). Quantifying archaeal community autotrophy in the mesopelagic ocean using natural radiocarbon. Proc. Natl. Acad. Sci. U.S.A. 103, 6442-6447. doi: 10.1073/pnas.0510157103 
Jiao, N., Herndl, G. J., Hansell, D. A., Benner, R., Kattner, G., Wilhelm, S. W., et al. (2010). Microbial production of recalcitrant dissolved organic matter: long-term carbon storage in the global ocean. Nat. Rev. Microbiol. 8, 593-599. doi: $10.1038 /$ nrmicro2386

Johnson, W. M., Longnecker, K., Kido Soule, M. C., Arnold, W. A., Bhatia, M. P., Hallam, S. J., et al. (2020). Metabolite composition of sinking particles differs from surface suspended particles across a latitudinal transect in the South Atlantic. Limnol. Oceanogr. 65, 111-127. doi: 10.1002/lno.11255

Kaiser, K., and Benner, R. (2008). Major bacterial contribution to the ocean reservoir of detrital organic carbon and nitrogen. Limnol. Oceanogr. 53, 99-112. doi: 10.4319/lo.2008.53.3.1192

Kawasaki, N., Sohrin, R., Ogawa, H., Nagata, T., and Benner, R. (2011). Bacterial carbon content and the living and detrital bacterial contributions to suspended particulate organic carbon in the North Pacific Ocean. Aquat. Microb. Ecol. 62, 165-176. doi: 10.3354/ame01462

Kharbush, J. J., Allen, A. E., Moustafa, A., Dorrestein, P. C., and Aluwihare, L. I. (2016). Intact polar diacylglycerol biomarker lipids isolated from suspended particulate organic matter accumulating in an ultraoligotrophic water column. Org. Geochem. 100, 29-41. doi: 10.1016/j.orggeochem.2016.07.008

Killops, S., and Killops, V. (2005). Introduction To Organic Geochemistry, 2nd Edn, Hoboken, NJ: Blackwell Publishing.

Koch, H., Dürwald, A., Schweder, T., Noriega-Ortega, B., Vidal-Melgosa, S., Hehemann, J. H., et al. (2019). Biphasic cellular adaptations and ecological implications of Alteromonas macleodii degrading a mixture of algal polysaccharides. ISME J. 13, 92-103. doi: 10.1038/s41396-018-0252-254

Krüger, K., Chafee, M., Ben Francis, T., Glavina del Rio, T., Becher, D., Schweder, T., et al. (2019). In marine Bacteroidetes the bulk of glycan degradation during algae blooms is mediated by few clades using a restricted set of genes. ISME J. 13, 2800-2816. doi: 10.1038/s41396-019-0476-y

Kujawinski, E. B. (2011). The impact of microbial metabolism on marine dissolved organic matter. Ann. Rev. Mar. Sci. 3, 567-599. doi: 10.1146/annurev-marine120308-181003

Laber, C. P., Hunter, J. E., Carvalho, F., Collins, J. R., Hunter, E. J., Schieler, B. M., et al. (2018). Coccolithovirus facilitation of carbon export in the North Atlantic. Nat. Microbiol. 3, 537-547. doi: 10.1038/s41564-018-0128-124

Laine, R. A. (1994). A calculation of all possible oligosaccharide isomers both branched and linear yields $1.05 \times 10^{\wedge} 12$ structures for a reducing hexasaccharide: the "isomer barrier" to development of single-method saccharide sequencing or synthesis systems. Glycobiology 4, 759-767. doi: 10. 1093/glycob/4.6.759

Lam, P. J., Doney, S. C., and Bishop, J. K. B. (2011). The dynamic ocean biological pump: insights from a global compilation of particulate organic carbon, $\mathrm{CaCO}$ 3 , and opal concentration profiles from the mesopelagic. Global Biogeochem. Cycles 25, 1-14. doi: 10.1029/2010GB003868

Larsen, T., Bach, L. T., Salvatteci, R., Wang, Y. V., Andersen, N., Ventura, M., et al. (2015). Assessing the potential of amino acid 13C patterns as a carbon source tracer in marine sediments: effects of algal growth conditions and sedimentary diagenesis. Biogeosciences 12, 4979-4992. doi: 10.5194/bg-12-4979-2015

Law, K. L. (2017). Plastics in the marine environment. Ann. Rev. Mar. Sci. 9, 205-229. doi: 10.1146/annurev-marine-010816-060409

Le Moigne, F. A. C. (2019). Pathways of organic carbon downward transport by the oceanic biological carbon pump. Front. Mar. Sci. 6:634. doi: 10.3389/fmars. 2019.00634

Legendre, L., Rivkin, R. B., Weinbauer, M. G., Guidi, L., and Uitz, J. (2015). The microbial carbon pump concept: potential biogeochemical significance in the globally changing ocean. Prog. Oceanogr. 134, 432-450. doi: 10.1016/j.pocean. 2015.01.008

Liu, Z., Mao, J., Peterson, M. L., Lee, C., Wakeham, S. G., and Hatcher, P. G. (2009). Characterization of sinking particles from the northwest Mediterranean Sea using advanced solid-state NMR. Geochim. Cosmochim. Acta 73, 1014-1026. doi: 10.1016/j.gca.2008.11.019

Llewellyn, C. A., and Mantoura, R. F. C. (1996). Pigment biomarkers and particulate carbon in the upper water column compared to the ocean interior of the northeast Atlantic. Deep. Res. Part I Oceanogr. Res. Pap. 43, 1165-1184. doi: 10.1016/0967-0637(96)00043-X

Logemann, J., Graue, J., Köster, J., Engelen, B., Rullkötter, J., and Cypionka, H. (2011). A laboratory experiment of intact polar lipid degradation in sandy sediments. Biogeosciences 8, 2547-2560. doi: 10.5194/bg-8-2547-2011
Luo, G., Yang, H., Algeo, T. J., Hallmann, C., and Xie, S. (2019). Lipid biomarkers for the reconstruction of deep-time environmental conditions. Earth Sci. Rev. 189, 99-124. doi: 10.1016/j.earscirev.2018.03.005

Mabeau, S., and Kloareg, B. (1987). Isolation and analysis of the cell walls of brown algae: Fucus spiralis, F. ceranoides, F. vesiculosus, F. serratus, Bifurcaria bifurcata and Laminaria digitata. J. Exp. Bot. 38, 1573-1580. doi: 10.1093/jxb/38.9.1573

Mao, J., Tremblay, L., and Gagné, J. P. (2011). Structural changes of humic acids from sinking organic matter and surface sediments investigated by advanced solid-state NMR: insights into sources, preservation and molecularly uncharacterized components. Geochim. Cosmochim. Acta 75, 7864-7880. doi: 10.1016/j.gca.2011.09.044

Martin, J. H., Knauer, G. A., Karl, D. M., and Broenkow, W. W. (1987). VERTEX: carbon cycling in the northeast Pacific. Deep. Res. 34, 267-285. doi: 10.1016/ 0198-0149(87)90086-0

McDonald, N., Achterberg, E. P., Carlson, C. A., Gledhill, M., Liu, S., MathesonBarker, J. R., et al. (2019). The role of heterotrophic bacteria and archaea in the transformation of lignin in the open ocean. Front. Mar. Sci. 6:743. doi: 10.3389/fmars.2019.00743

McMahon, K. W., McCarthy, M. D., Sherwood, O. A., Larsen, T., and Guilderson, T. P. (2015). Millennial-scale plankton regime shifts in the subtropical North Pacific Ocean. Science 350, 1530-1533. doi: 10.1126/science.aaa9942

McNaught, A. D., and Wilkinson, A. (eds) (1997). "International union of pure and applied," in Compendium of Chemical Terminology (the Gold Book), 2nd Edn (Oxford: Blackwell Scientific Publications).

Mestre, M., Ferrera, I., Borrull, E., Ortega-Retuerta, E., Mbedi, S., Grossart, H. P., et al. (2017). Spatial variability of marine bacterial and archaeal communities along the particulate matter continuum. Mol. Ecol. 26, 6827-6840. doi: 10.1111/ mec. 14421

Mestre, M., Ruiz-González, C., Logares, R., Duarte, C. M., Gasol, J. M., and Sala, M. M. (2018). Sinking particles promote vertical connectivity in the ocean microbiome. Proc. Natl. Acad. Sci. U.S.A. 115, E6799-E6807. doi: 10.1073/pnas. 1802470115

Moore, E. K., Nunn, B. L., Goodlett, D. R., and Harvey, H. R. (2012). Identifying and tracking proteins through the marine water column: insights into the inputs and preservation mechanisms of protein in sediments. Geochim. Cosmochim. Acta 83, 324-359. doi: 10.1016/j.gca.2012.01.002

Nouara, A., Panagiotopoulos, C., Balesdent, J., Violaki, K., Bard, E., Fagault, Y., et al. (2019). Liquid chromatographic isolation of individual carbohydrates from environmental matrices for stable carbon analysis and radiocarbon dating. Anal. Chim. Acta 1067, 137-146. doi: 10.1016/j.aca.2019.03.028

Ohkouchi, N., Chikaraishi, Y., Close, H. G., Fry, B., Larsen, T., Madigan, D. J., et al. (2017). Advances in the application of amino acid nitrogen isotopic analysis in ecological and biogeochemical studies. Org. Geochem. 113, 150-174. doi: 10.1016/j.orggeochem.2017.07.009

Panagiotopoulos, C., and Sempéré, R. (2005). Analytical methods for the determination of sugars in marine samples: a historical perspective and future directions. Limnol. Oceanogr. Methods 3, 419-454. doi: 10.4319/lom.2005. 3.419

Peng, G., Bellerby, R., Zhang, F., Sun, X., and Li, D. (2020). The ocean's ultimate trashcan: hadal trenches as major depositories for plastic pollution. Water Res. 168, 115121. doi: 10.1016/j.watres.2019.115121

Petras, D., Koester, I., Da Silva, R., Stephens, B. M., Haas, A. F., Nelson, C. E., et al. (2017). High-resolution liquid chromatography tandem mass spectrometry enables large scale molecular characterization of dissolved organic matter. Front. Mar. Sci. 4:405. doi: 10.3389/fmars.2017.00405

Popendorf, K. J., Lomas, M. W., and Van Mooy, B. A. S. (2011). Microbial sources of intact polar diacylglycerolipids in the Western North Atlantic Ocean. Org. Geochem. 42, 803-811. doi: 10.1016/j.orggeochem.2011.05.003

Porter, A., Lyons, B. P., Galloway, T. S., and Lewis, C. (2018). Role of marine snows in microplastic fate and bioavailability. Environ. Sci. Technol. 52, 7111-7119. doi: 10.1021/acs.est.8b01000

Prahl, F. G., and Wakeham, S. G. (1987). Calibration of unsaturation patterns in long-chain ketone compositions for palaeotemperature assessment. Nature 330, 367-369. doi: 10.1038/330367a0

Preston, C. M., Durkin, C. A., and Yamahara, K. M. (2020). DNA metabarcoding reveals organisms contributing to particulate matter flux to abyssal depths in the North East Pacific ocean. Deep. Res. Part II Top. Stud. Oceanogr. 173:104708. doi: $10.1016 /$ j.dsr2.2019.104708 
Reisky, L., Préchoux, A., Zühlke, M. K., Bäumgen, M., Robb, C. S., Gerlach, N., et al. (2019). A marine bacterial enzymatic cascade degrades the algal polysaccharide ulvan. Nat. Chem. Biol. 15, 803-812. doi: 10.1038/s41589-019-0311-319

Repeta, D. J., and Gagosian, R. B. (1984). Transformation reactions and recycling of carotenoids and chlorins in the Peru upwelling region $\left(15^{\circ} \mathrm{S}, 75^{\circ} \mathrm{W}\right)$. Geochim. Cosmochim. Acta 48, 1265-1277. doi: 10.1016/0016-7037(84)90061-90069

Riley, J. S., Sanders, R., Marsay, C., Le Moigne, F. A. C., Achterberg, E. P., and Poulton, A. J. (2012). The relative contribution of fast and slow sinking particles to ocean carbon export. Global Biogeochem. Cycles 26, 1-10. doi: 10.1029/ 2011GB004085

Roland, L. A., McCarthy, M. D., and Guilderson, T. (2008). Sources of molecularly uncharacterized organic carbon in sinking particles from three ocean basins: a coupled $\triangle 14 \mathrm{C}$ and $813 \mathrm{C}$ approach. Mar. Chem. 111, 199-213. doi: 10.1016/j. marchem.2008.05.010

Sabadel, A. J. M., Van Oostende, N., Ward, B. B., Woodward, E. M., Van Hale, R., and Frew, R. D. (2019). Characterization of particulate organic matter cycling during a summer North Atlantic phytoplankton bloom using amino acid C and N stable isotopes. Mar. Chem. 214:103670. doi: 10.1016/j.marchem.2019. 103670

Saito, M. A., Bertrand, E. M., Duffy, M. E., Gaylord, D. A., Held, N. A., Hervey, W. J., et al. (2019). Progress and challenges in ocean metaproteomics and proposed best practices for data sharing. J. Proteome Res. 18, 1461-1476. doi: 10.1021/acs.jproteome.8b00761

Salmeán, A. A., Guillouzo, A., Duffieux, D., Jam, M., Matard-Mann, M., Larocque, R., et al. (2018). Double blind microarray-based polysaccharide profiling enables parallel identification of uncharacterized polysaccharides and carbohydrate-binding proteins with unknown specificities. Sci. Rep. 8, 1-11. doi: 10.1038/s41598-018-20605-20609

Schouten, S., Hopmans, E. C., Schefuß, E., and Sinninghe-Damsté, J. S. (2002). Distributional variations in marine crenarchaeotal membrane lipids: a new tool for reconstructing ancient sea water temperatures? Earth Planet Sci. Lett. 204, 265-274. doi: 10.1016/s0012-821x(02)00979-2

Schubotz, F., Xie, S., Lipp, J. S., Hinrichs, K. U., and Wakeham, S. G. (2018). Intact polar lipids in the water column of the eastern tropical North Pacific: abundance and structural variety of non-phosphorus lipids. Biogeosciences 15, 6481-6501. doi: 10.5194/bg-15-6481-2018

Sinninghe Damsté, J. S., Strous, M., Rijpstra, W. I. C., Hopmans, E. C., Geenevasen, J. A. J., Van Duin, A. C. T., et al. (2002). Linearly concatenated cyclobutane lipids form a dense bacterial membrane. Nature 419, 708-712. doi: 10.1038/ nature 01128

Sollai, M., Villanueva, L., Hopmans, E. C., Reichart, G. J., and Sinninghe Damsté, J. S. (2019). A combined lipidomic and 16S rRNA gene amplicon sequencing approach reveals archaeal sources of intact polar lipids in the stratified Black Sea water column. Geobiology 17, 91-109. doi: 10.1111/gbi. 12316

Tao, S., Eglinton, T. I., Montluçon, D. B., McIntyre, C., and Zhao, M. (2015). Preaged soil organic carbon as a major component of the yellow river suspended load: regional significance and global relevance. Earth Planet. Sci. Lett. 414, 77-86. doi: 10.1016/j.epsl.2015.01.004

Teeling, H., Fuchs, B. M., Becher, D., Klockow, C., Gardebrecht, A., Bennke, C. M., et al. (2012). Substrate-controlled succession of marine bacterioplankton populations induced by a phytoplankton bloom. Science 336, 608-611. doi: $10.1126 /$ science. 1218344

Teeling, H., Fuchs, B. M., Bennke, C. M., Krüger, K., Chafee, M., Kappelmann, L., et al. (2016). Recurring patterns in bacterioplankton dynamics during coastal spring algae blooms. eLife 5:11888. doi: 10.7554/eLife.11888

Thiele, S., Basse, A., Becker, J. W., Lipski, A., Iversen, M. H., and Mollenhauer, G. (2019). Microbial communities in the nepheloid layers and hypoxic zones of the canary current upwelling system. Microbiologyopen 8, 1-13. doi: 10.1002/mbo3. 705

Tremblay, L., Alaoui, G., and Léger, M. N. (2011). Characterization of aquatic particles by direct FTIR analysis of filters and quantification of elemental and molecular compositions. Environ. Sci. Technol. 45, 9671-9679. doi: 10.1021/ es202607n

Tremblay, L., Caparros, J., Leblanc, K., and Obernosterer, I. (2015). Origin and fate of particulate and dissolved organic matter in a naturally iron-fertilized region of the Southern Ocean. Biogeosciences 12, 607-621. doi: 10.5194/bg-12-6072015

Van Mooy, B. A. S., Fredricks, H. F., Pedler, B. E., Dyhrman, S. T., Karl, D. M., Koblízek, M., et al. (2009). Phytoplankton in the ocean use non-phosphorus lipids in response to phosphorus scarcity. Nature 458, 69-72. doi: 10.1038/ nature07659

Van Mooy, B. A. S., Keil, R. G., and Devol, A. H. (2002). Impact of suboxia on sinking particulate organic carbon: enhanced carbon flux and preferential degradation of amino acids via denitrification. Geochim. Cosmochim. Acta 66, 457-465. doi: 10.1016/S0016-7037(01)00787-786

Volk, T., and Hoffert, M. I. (1985). "Ocean carbon pumps: analysis of relative strengths and efficiencies in ocean-driven atmospheric $\mathrm{CO}_{2}$ changes," in The Carbon Cycle and Atmospheric CO2: Natural Variations Archean to Present, eds E. Sundquist and W. Broecker (Washington, DC: American Geophysical Union), 99-110. doi: 10.1029/gm032p0099

Volkman, J. (2016). “Sterols in microalgae," in The Physiology of Microalgae, eds M. Borowitzka, J. Beardall, and J. Raven (Berlin: Springer), 485-505. doi: 10.1007/ 978-3-319-24945-2_19

Wagner, S., Brandes, J., Spencer, R. G. M., Ma, K., Rosengard, S. Z., Moura, J. M. S., et al. (2019). Isotopic composition of oceanic dissolved black carbon reveals non-riverine source. Nat. Commun. 10, 1-8. doi: 10.1038/s41467-019-1311113117

Wagner, S., Jaffé, R., and Stubbins, A. (2018). Dissolved black carbon in aquatic ecosystems. Limnol. Oceanogr. Lett. 3, 168-185. doi: 10.1002/lol2.10076

Wagner, S., Schubotz, F., Kaiser, K., Hallmann, C., Waska, H., Rossel, P. E., et al. (2020). Soothsaying DOM: a current perspective on the future of oceanic dissolved organic carbon. Front. Mar. Sci. 7:341. doi: 10.3389/fmars.2020.00341

Wakeham, S. G., and Beier, J. A. (1991). Fatty acid and sterol biomarkers as indicators of particulate matter source and alteration processes in the Black Sea. Deep. Res. Part A 38, S943-S968. doi: 10.1016/s0198-0149(10)80018-80014

Wakeham, S. G., Lee, C., Farrington, J. W., and Gagosian, R. B. (1984). Biogeochemistry of particulate organic matter in the oceans: results from sediment trap experiments. Deep Sea Res. Part A. Oceanogr. Res. Pap. 31, 509-528. doi: 10.1016/0198-0149(84)90099-90092

Wakeham, S. G., Lee, C., and Hedges, J. I. (2000). "Fluxes of major biochemicals in the equatorial Pacific Ocean," in Dynamics and Characterization of Marine Organic Matter, eds N. Handa, E. Tanoue, and T. Hama (Dordrecht: Springer), 117-140. doi: 10.1007/978-94-017-1319-1_6

Wakeham, S. G., Lee, C., Hedges, J. I., Hernes, P. J., and Peterson, M. L. (1997). Molecular indicators of diagenetic status in marine organic matter. Geochim. Cosmochim. Acta 61, 5363-5369. doi: 10.1016/S0016-7037(97)00312-318

Wang, X. C., and Druffel, E. R. M. (2001). Radiocarbon and stable carbon isotope compositions of organic compound classes in sediments from the NE Pacific and Southern Oceans. Mar. Chem. 73, 65-81. doi: 10.1016/S0304-4203(00) 00090-96

Weber, T., Cram, J. A., Leung, S. W., DeVries, T., and Deutsch, C. (2016). Deep ocean nutrients imply large latitudinal variation in particle transfer efficiency. Proc. Natl. Acad. Sci. U.S.A. 113, 8606-8611. doi: 10.1073/pnas.1604414113

White, D. C., Davis, W. M., Nickels, J. S., King, J. D., and Bobbie, R. J. (1979). Determination of the sedimentary microbial biomass by extractible lipid phosphate. Oecologia 40, 51-62. doi: 10.1007/bf00388810

Woo, H. L., and Hazen, T. C. (2018). Enrichment of bacteria from Eastern Mediterranean Sea involved in lignin degradation via the phenylacetyl-CoA pathway. Front. Microbiol. 9:922. doi: 10.3389/fmicb.2018.00922

Zalasiewicz, J., Waters, C. N., Ivar do Sul, J. A., Corcoran, P. L., Barnosky, A. D., Cearreta, A., et al. (2016). The geological cycle of plastics and their use as a stratigraphic indicator of the anthropocene. Anthropocene 13, 4-17. doi: 10. 1016/j.ancene.2016.01.002

Zhou, A., Weber, Y., Chiu, B. K., Elling, F. J., Cobban, A. B., Pearson, A., et al. (2020). Energy flux controls tetraether lipid cyclization in Sulfolobus acidocaldarius. Environ. Microbiol. 22, 343-353. doi: 10.1111/1462-2920.14851

Conflict of Interest: The authors declare that the research was conducted in the absence of any commercial or financial relationships that could be construed as a potential conflict of interest.

Copyright (c) 2020 Kharbush, Close, Van Mooy, Arnosti, Smittenberg, Le Moigne, Mollenhauer, Scholz-Böttcher, Obreht, Koch, Becker, Iversen and Mohr. This is an open-access article distributed under the terms of the Creative Commons Attribution License (CC BY). The use, distribution or reproduction in other forums is permitted, provided the original author(s) and the copyright owner(s) are credited and that the original publication in this journal is cited, in accordance with accepted academic practice. No use, distribution or reproduction is permitted which does not comply with these terms. 